\title{
El duelo revelado. La vida social de las fotografías familiares de las víctimas del franquismo
}

\author{
MORENO ANDRÉS, Jorge \\ Consejo Superior de Investigaciones Científicas, Madrid, 2018
}

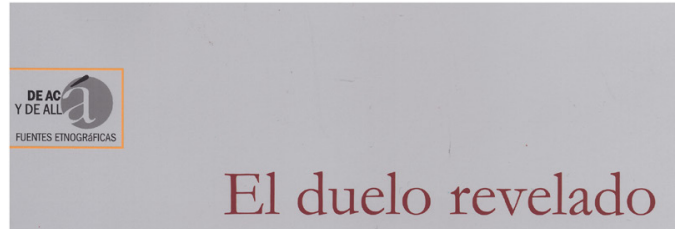

La vida social de las fotografías familiares de las víctimas del franquismo

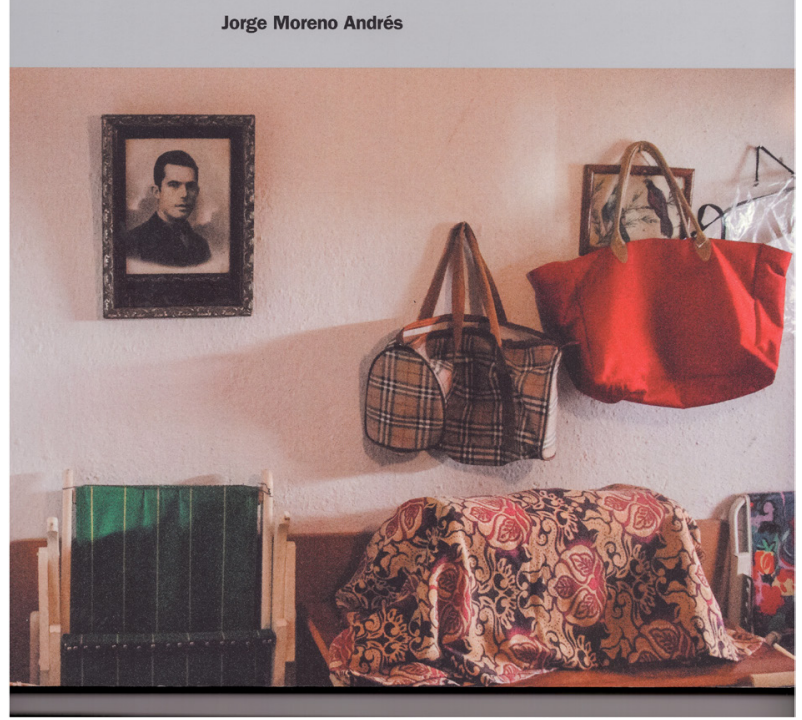

Hay una cita de De Certeau que se repite varias veces a lo largo del libro de Jorge Moreno: «En un espacio en que los fuertes siempre ganan, las palabras (y las imágenes) siempre engañan». Por ello, porque engañan, es imprescindible pararnos a mirarlas, analizarlas, entenderlas, sentirlas... en una apuesta en la que el autor va un poquito más allá de lo que en principio podríamos pensar. Me explico. Lo normal sería esperar de este libro un mejor conocimiento de la experiencia de lo político (en el sentido en que lo entiende Ranciére) de algunos de los «perdedores» del franquismo a través de las imágenes que conservan, de cómo y dónde las conservan, de qué «vida» les han dado. Entenderíamos así que el régimen tuvo dos grandes líneas de intervención sobre la población «resistente»: por un lado la obvia, la públicamente violenta, estupendamente explicitada en el libro y que abarcaría desde la cárcel hasta el fusilamiento y el mal entierro en la fosa; y por otro, una línea que apunta a un control más privado y, por lo tanto, más sutilmente agresivo, un control que en el libro nos pasa ante los ojos en forma de espionaje sobre la correspondencia tanto de los presos o presas como de los exiliados, o en la insistente visita diaria de un guardia civil a una casa particular para comprobar simplemente la posición de un retrato impuesto. Controles contra los que las formas de resistencia que gestionaban las familias eran tan sutiles como imaginativas y que dan una lectura diferente a la cita de De Certeau: al mismo tiempo que las imágenes engañan sobre la realidad al estar «al servicio» del poder, también son capaces de «engañar» a ese mismo poder para pasar, como de contrabando, las noticias que unos esperan de los otros en fotografías aparentemente «normales» (turísticas, sumisas...) que quedan ahí, entre los restos del imaginario del poder, en espera de que alguien vuelva a intentar leerlas, algo que solo es posible hacer si se atiende cuidadosamente a su contexto.

Eso esperaríamos y eso el libro nos lo da con creces mientras nos cuenta las historias de una difícil supervivencia, la de los derrotados, una supervivencia que, como señala Julián López García se puede/se debe leer también en términos de resistencia. De ahí que el libro se divida en cuatro grandes capítulos ocupados del legado, la esperanza, el arraigo y la resurrección. Es importante quién conserva esas imágenes, dónde y por qué; como es importante la vida social de cada imagen: los itinerarios y contextos por lo que ha transitado, los lugares en los que ha descansado, las narrativas que la han acompañado... todo ello, algunas veces, más importante que la imagen en sí. Y es que el libro, construido a partir de una excelente y meticulosa metodología en la que no se escatiman ni lecturas ni entrevistas ni emociones, es un homenaje a la memoria como uno de los 
modos más eficaces de resistencia: resistencia de cada uno de los familiares que han mantenido vivas y políticamente operativas las imágenes de sus represaliados, resistencia que nos propone a todos el mismo Jorge Moreno al invitarnos a ocuparnos de esas imágenes para que las víctimas mantengan la humanidad que con tanta dificultad conservaron sus familiares. De hecho, el autor habla de «fotografías inhumanadas», fotografías que permitieron a las familias resistir a la animalización a que se vio sometida, de un modo oficial y cuidadosamente estipulado, la muerte de sus seres queridos en las fosas en que han permanecido enterrados.

Lo curioso, y ese es el extra que nos regala el libro, es que en esa obsesión por sostener la humanidad del represaliado a partir de unas imágenes empeñadas en mantener la «emanación» barthesiana, la «impresión» umbilical del sujeto sobre su imagen, empiezan a aparecer en la fotografía los fantasmas, los espectros. Y los espectros, como ya sabemos, interpelan con una insistencia indestructible porque con ellos siempre hay cuentas pendientes. Derrida lo tenía muy claro: el fantasma quiere dar cuenta de una herencia que tenemos con respecto a algo y, por lo tanto, escuchar al fantasma implica darle la palabra a lo que no la tuvo, a aquellos espectros, como dijo Deleuze, «enterrados demasiado pronto o demasiado profundo» y que, por lo tanto, no han logrado constituirse en recuerdo sino en ausencia.

Todo el libro de Jorge Moreno está construido con los espectros: Ios espectros que convocaban los familiares que con tanto cuidado mantuvieron la imagen de sus desaparecidos y no solo para llenar su ausencia, los espectros que ahora convocamos nosotros para entender no sólo a los que aparecen en el libro sino también a los nuestros propios. Entendiendo y exponiendo con cuidadoso respeto el dolor y el cuidado de las familias, Jorge Moreno contribuye, y nos hace cómplices de ello, a que la ausencia empiece a convertirse en recuerdo... para todos.

Yayo Aznar Universidad Nacional de Educación a Distancia 